\title{
ANALISIS ANGGARAN PENDAPATAN DAN BELANJA DAERAH KABUPATEN / KOTA DI PROVINSI SUMATERA UTARA
}

\section{REVENUE AND EXPENDITURE BUDGET ANALYSIS OF CITIES IN NORTH SUMATERA PROVINCE}

\author{
Murni Dahlena ${ }^{1}$, Junita Putri Rajana ${ }^{2}$ \\ Universitas Muslim Nusantara Al-Washliyah ${ }^{1,2}$ \\ murnidahlenanst@umnaw.ac.id ${ }^{1}$
}

\begin{abstract}
$A P B D$ shows the potential ability of a region to manage its regional resources to be a source of income in the context of regional development and prosperity. This research was conducted to analyze and identify the financial capacity of the region for the purposes of planning the following year or other interests. Regional Revenue and Expenditure Budget (APBD) is a financial plan prepared by each region based on Regional Regulations, in this case the regency / city area in North Sumater Province. This study uses district / city APBD data in North Sumatra Province for the past 4 years, from 2014 to 2017. The results of this study indicate that the financial performance of district / city governments in North Sumatra Province is good and independent, marked by the large components Regional original income continues to increase from 2014 to 2017.
\end{abstract}

Keywords : Revenue, Expenditure, Performance

\begin{abstract}
ABSTRAK
APBD menunjukkan kemampuan potensial suatu daerah dalam mengelola sumber daya daerahnya untuk dijadikan sumber pendapatan dalam rangka pembangunan serta kesejahteraan daerah. Penelitian ini dilakukan untuk menganalisis dan mengidentifikasi kemampuan keuangan daerah untuk kepentingan perencanaan tahun berikutnya atau kepentingan lainnya. Anggaran Pendapatan dan Belanja daerah (APBD) merupakan rencana keuangan yang dipersiapkan oleh masing-masing daerah berdasarkan Peraturan Daerah, dalam hal ini adalah daerah kabupaten/kota yang ada di Provinsi Sumater Utara. Penelitian ini menggunakan dat APBD kabupaten/kota yang ada di Provinsi Sumatera Utara selama 4 tahun terakhir yaitu tahun 2014 sampai dengan 2017. Hasil penelitian ini menunjukkan bahwa kinerja keuangan pemerintah kabupaten / kota yang ada di Provinsi Sumatera Utara sudah baik dan mandiri ditandai dengan besarnya komponen pendapatan asli daerah yang terus meningkat dari tahun 2014 sampai dengan tahun 2017.
\end{abstract}

Kata Kunci : Pendapatan, Belanja, Kinerja 
PENDAHULUAN

Pemerintah

daerah

menggunakan Aggaran Pendapatan dan Belanja Daerah (APBD) untuk merencanakan keuangan pemerintah daerah selama 1 tahun anggaran. APBD dibahas dan disetujui bersama oleh Pemerintah Daerah dan Dewan Perwakilan Rkyat Daerah (DPRD) dan hasilnya ditetapkan dengan ketentuan Perturan Daerah.

$$
\text { APBD menunjukkan }
$$

kemampuan potensial suatu daerah dalam mengelola sumber daya daerahnya untuk dijadikan sumber pendapatan dalam rangka pembangunan serta kesejahteraan daerah. APBD yang dianggarkan memiliki dketerkaitan dengan Anggaran Pendapatan dan Belanja Negara (APBN), karena sumber pendapatan suatu daerah tidak hanya bersumber dari daerah itu sendiri. Didalam komponen APBD suatu daerah juga terdapat anggaran dana transfer dari pemerintah pusat yang tertuang dalam APBN. Dengan adanya keterkaitan APBD dan APBN maka pemerintah daerah harus dapat mencapai dan atau menciptakan pola belanja yang ideal, yaitu pola belanja yang seimbang dengan pendapatan.

Hal ini bertujuan agar pemerintah daerah tidak mengalami defisit, yauitu anggaran belanja yang lebih tinggi dari pendapatan daerah itu sendiri. Selain itu apabila pemerintah daerah meniliki pola belanja yang lebih tinggi dari pendapatan daerah, maka pemerintah pusat tentu akan menganggarkan bantuan dalam bentuk dna transfer kepada pemerintah daerah. Kondisi keuangan pemerintah daerah dengan sumber dana transfer yang lebh besar dari pendapatan asli daerah itu sendiri akan menunjukkan bahwa daerah tersebut memiliki tingkat kemandirian yang rendah.
Kinerja keuangan adalah ukuran pencapaian suatu program keuangan yang telah dianggarkan pemerintah daerah dan diukur dengan tingkat pencapaian realisasi yang didapat. Kinerja keuangan yang baik apabila rencana keuangan yang dianggarkan dapat terealisasi dengan sempurna. Kinerja keuangan yang baik juga terpenuh dengan terealisasi nya kemandirian suatu daerah, dimana komponen sumber pendapatan asli daerah yang lebih besar dari komponen sumber dana transfer (Haryani, 2016)..

Anggaran Pendapatan dan Belanja (APBD) merupakan suatu rencana kerja kuantitatif pemerintah yang dinyatakan dalam satuan moneter. Komponen APBD mencerminkan sumber-sumber penerimaan dan pengeluaran pemerintah daralm rangka membiayai kegiatan daerah selama 1 (satu) tahun anggaran. APBD dapat dijadikan salah satu alat untuk melaksanakan pelayanan kepada masyarakat dalam rangka meningkatkan kesejahteraan masyarakat demi tercapainya tujuan otonomi daerah yang luas, nyata dan bertanggungjawab (Haryani, 2016).

Proses penyusunan APBDharus benar-benar dilaksanakan dengan mempertimbangkan kebutuhan masyarakat dan tetap memperhatikan potensi keanekaragaman sumber daya yang ada di daerah tersebut. Komponen APBD terdiri dari pendapatan, belanja dan pembiayaan. Komponen pendapatan yang ada di Pendapatan daerah terdiri dari 3 (tiga) sumber yaitu : Pendapatan Asli Daerah (PAD), Dana Perimbangan, dan Lain-Lain Pendapaan Daerah yang Sah (Sinambela, 2016).

Selanjutnya, komponen belanja yang ada di dalam APBD terdiri dari : Belanja Langsung dan Belanja Tak Langsung. Belanja langsung terdiri dari 
Belanja Aparatur Daerah, Belanja Pelayanan Publik, Belanja Bagi Hasil dan Bantuan Keuangan. Belanja Tak Langsung. diklasifikasikan menjadi 3 kategori yaitu Belanja Administrasi Umum, Belanja Operasi dan Pemeliharaan, dan Belanja Modal / Pembangunan. Belanja Pelayanan Publik dikelompokkan menjadi 3 yakni Belanja Administrasi Umum, Belanja Operasional dan Pemeliharaan, serta Belanja Modal.

Pembiayaan merupakan komponen APBD yang terakhir, pembiayaan adalah sumber - sumber penerimaan dan pengeluaran daerah yang dimaksudkan untuk menutup defisit anggaran atau sebagai alokasi surplus anggaran (Suryantini, 2017). Menurut kelompok sumbernya, pembiayaan terdiri dari: sumber penerimaan daerah dan sumber pengeluaran daerah. Sumber pembiayaan berupa penerimaan daerah adalah: sisa lebih anggaran tahun lalu, penerimaan pinjaman dan obligasi, hasil penjualan aset daerah yang dipisahkan, dan transfer dari dana cadangan. Sedangkan sumber pembiayaan berupa pengeluaran daerah terdiri atas: pembayaran utang pokok yang telah jatuh tempo, penyertaan modal, transfer ke dana cadangan, dan sisa lebih anggaran tahun sekarang (Ramadhani, 2016).

$$
\text { Menurut Undang-Undang }
$$

Nomor 23 Tahun 2014 tentang Pemerintahan Daerah, Pendapatan Daerah merupakan hak Pemerintah Daerah yang diakui sebagai penambah nilai kekayaan bersih dalam periode tahun anggaran yang bersangkutan. Hak yang dimaksud dalam pendapatan daerah adalah semua penerimaan uang melalui rekening kas umum daerah, yang menambah ekuitas dana dan tidak perlu dibayar kembali oleh daerah. Sumber pendapatan daerah terdiri atas
Pendapatan Asli Daerah, Pendapatan Transfer dan Lain-Lain Pendapatan Daerah yang Sah (Risyanto, 2015). Pengelolaan pendapatan daerah sangat penting dilakukan agar dapat mengoptimalkan sumber pendapatan daerah dalam rangka meningkatkan kapasitas fiskal daerah tersebut dalam rangka memaksimalkan penyelenggaraan pemerintahan untuk pelayanan kepada masyarakat.

Dalam menganalisis belanja daerah, terdapat ketentuan bahwa belanja yang telah dianggarkan dengan batas maksimum pengeluaran yang boleh dilaksanakan oleh pemerintah daerah. Belanja daerah dapat mencerminkan kinerja pemerintah daerah baik atau buruk. Kinerja pemerintah daerah dikatakan baik pabila realisasi belanja tidak melebihi dari yang telah dianggarkan, begitu jug sebaliknya. Analisis varians juga dapat dilakukan untuk menilai apakah realisasi belanja daerah telah berjalan efektif dan efisien sesuai yang telah dianggarkan.

Berdasarkan Laporan Realisasi Anggaran yang dibuat oleh pemerintah, pembaca laporan dapat memperoleh informasi secara langsung besarnya varians anggaran belanja dengan realisasinya yang dapat dinyatakan dengan nilai nominal atau besarnya persentasi perbedaan. bisa dinyatakannya dalam nilai nominalnya atau presentasenya (Hiariey, 2017)

Selisih anggaran belanja daerah dikategorikan dua jenis, yaitu: selisih disukai (favourable variance), dan selisih tidak disukai (unfavourable variance). Favourable variance terjadi apabila realisasi belanja lebih kecil dari yang telah dianggarkan, sedangkan unfavourable variance terjadi jika realisasi belanja lebih besar dari yang telah 
dianggarkan. Dalam menganalisis varians belanja daerah terdapat beberapa hal penting yang perlu diperhtikan, antara lain : mengapa terjadi varanians, apakah varians yang terjadi cukup beralasan dan dapat dipertanggungjawabkan ? Berapa besarnya nilai varins, apakah jumlahnya signifikan, berapa tingkat varians yang bisa ditoleransi, dan lain sebagainya (Kaeng \& Saerang, 2017)

Keuangan daerah merupakan kemampuan pemerintah daerah dalam mengelola keungan yang dimulai dari tahap perencanaan, pelaksanaan, pengawasan, pengendalian dan pengevaluasian berbagai sumber keuangan sesuai dengan kewenangan pemerintah daerah dalam rangka terwujudnya tujuan desentralisasi

Menurut UU No.17 Tahun 2003, keuangan daerah adalah semua hak dan kewajiban pemerintah daerah dalam rangka penyelenggaraan pemerintah daerah yang dapat dinilai dengan uang, serta segala sesuatu baik berupa uang maupun barang yang dapat dijadikan milik daerah berhubungan dengan pelaksanaan hak dan kewajiban daerah tersebut. Ruang lingkup keuangan daerah meliputi : 1) hak daerah untuk memungut pajak dan retribusi daerah serta melakukan pinjaman, 2) kewajiban daerah untuk menyelenggarakn urusan pemerintahan daerah, 3) penerimaan dan pengeluaran daerah, 4) kekayaan daerah yang dikelola sendiri atau oleh pihak lain, dan 4) kekayaan pihak lain yang dikuasai oleh pemerintah daerah dlam rangka penyelenggaraan tugas pemerintahan dan / atau kepentingan umum

Beberapa penelitian telah melakukan analisa terhadap APBD dari berbagai daerah di Indonesia dengan menggunakan metode analisa yang berbeda-beda (Suryantini, 2017;
Ramadhani 2016; Hiariey 2017) . Untuk itu, penelitian ini dilakukan untuk mengetahui tingkat realisasi APBD, komponen keuangan, pola belanja dan tingkat kemandirian keuangan kabupaten/kota yang ada di Provinsi Sumatera Utara mulai dari tahun 2014 sampai dengan 2017.

\section{METODE PENELITIAN}

Penelitian ini dilaksanakan dengan menggunakan teknik analisa kualitatif. Data atau informasi berbentuk angka-angka yang nantinya akan ditarik kesimpulan dengan cara membandingkan data yang satu dengan yang lainnya. Analisis data yang digunakan pada penelitian ini adalah analisis deskriptif, yaitu memberikan penjelasan denagn melihat perkembangan kinerja keuangan pemerintah kabupaten/kota yang ada di Provinsi Sumatera Utara. Data penelitian bersumber dari Laporan APBD dan Laporan Realisasi Anggaran seluruh kabupaten / kota yang ada di Provinsi Sumatera Utara.

\section{HASIL DAN PEMBAHASAN}

Anggaran Pendapatan dan Belanja Daerah (APBD) sebagai bentuk perencanaan pembangunan daerah yang memuat program-program pembangunan secara rinci sekaligus dengan sumber pembiayaannya. Sejalan dengan tujuan otonomi dan desentraliasi, maka pemerintah daerah diharapkan dapat mandiri dalam mengelola keuangannya.

Besaran kontribusi pengeluaran pemerintah daerah sangat berpengaruh terhadap pengeluaran pemerintah daerah yang berkaitan dengan pertumbuhan ekonomi. Program pembangunan dinyatakan dalam satuan moneter dan dianggarkan dalam APBD yang seyogyanya merupakan bentuk terencana yang dilakukan pemerintah 
untuk menghasilkan kapasitas pemerintahan dengan kemampuan yang handal, profesional, yang bertujuan untuk meningkatkan taraf hidup kesejahteraan masyarakat. Berikut ini adalah gambaran komposisi anggaran pendapatan dan belanja daerah kabupaten dan kota yang ada di Provinsi Sumatera Utara selama tahun 2014 sampai dengan tahun 2017 yang tertuang dalam tabel 1 berikut ini :

Tabel 1 Sumber Pendapatan Pemerintah Kabupaten/Kota di Provinsi Sumatera Utara

\begin{tabular}{|c|c|c|c|c|c|}
\hline No & Jenis Penerimaan & 2014 & 2015 & 2016 & 2017 \\
\hline A. & Pendapatan Daerah & 7.772 .029 .153 & 8.480 .758 .953 & 9.973 .988 .772 & 12234837882 \\
\hline 1. & Pendapatan Asli Daerah & 4.416 .811 .865 & 4.883 .880 .619 & 4. 630.468 .148 & 5287469402 \\
\hline 1.1. & Pajak Daerah & 4.054 .634 .671 & 4.427 .143 .659 & 4. 168.615 .292 & 4823549139 \\
\hline 1.2. & Retribusi Daerah & 78.49 .614 & 36.071 .947 & 31.964 .609 & 34289674 \\
\hline 1.3. & $\begin{array}{l}\text { Hasil Perusahaan Milik Daerah \& } \\
\text { Pengelolaan } \\
\text { Kekayaan Daerah yang Dipisahkan }\end{array}$ & 156.330 .873 & 25.240 .903 & 261.613 .672 & 195827847 \\
\hline 1.4 & Lain-lain PAD yang Sah & 127.348 .707 & 170.424 .110 & 168.274 .575 & 233802741 \\
\hline 2. & Dana Perimbangan & 1.812 .638 .981 & 1.521 .253 .168 & 2.272 .745 .765 & 6928134940 \\
\hline 2.1. & Bagi Hasil Pajak & 380.468 .139 & 313.793 .086 & 485.325 .624 & 446154989 \\
\hline 2.2 & $\begin{array}{l}\text { BagiHasilBukan Pajak/SumberDaya } \\
\text { Alam }\end{array}$ & 23.310 .178 & 20.451 .831 & 30.591 .978 & 14702345 \\
\hline 2.3 & Dana Alokasi Umum & 1.349 .132 .276 & 1.139 .261 .371 & 1.604 .505 .673 & 2629224545 \\
\hline 2.4 & Dana Alokasi Khusus & 59728388 & 47.746 .880 & 152.322 .490 & 3.838 .053 .061 \\
\hline 3. & Lain-lain Pendapatan yang Sah & 1542578307 & 2.075 .625 .166 & 3.070 .774 .859 & 19.233 .540 \\
\hline B. & Pembiayaan Daerah & 51426062 & 14.897 .906 & 1.123 .954 & 357.472 \\
\hline
\end{tabular}

Sumber : Data Olahan (2020)

Tahun 2014, dari keseluruhan total pendapatan yang diterima oleh pemerintah Provinsi Sumatera Utara, pajak daerah memberikan kontribusi yang paling besar diantara sumber pendapatan lainnya. Rasio Perbandingan sumber pendapatan asli daerah dan sumber pendapatan yang berasal dari bantuan pusat adalah $85 \%$. Dana perimbangan merupakan alokasi dana yang bersumber dari pemerintah pusat (APBN). Dana perimbangan memiliki nilai yang cukup besar di tahun 2014 yaitu Rp 1.812.638.981, namun jika dinilai secara keseluruhan masih relatif kecil dari sumber pendapatan yang lain.
Tahun 2015, pendapatan daerah mengalami kenaikan sebesar sebesar $10 \%$ dari 7.772.029.153 menjadi 8.480.758.953 dari tahun sebelumnya, dan diikuti pula dengan meningkatnya pendapatan asli daerah dari tahun sebelumnya. Komposisi sumber pendapatan asli daerah paling tinggi berasal dari pajak dibandingkan sumber dana bantuan pemerintah pusat. Dana perimbangan mengalami penurunan sebesar $8,4 \%$ yaitu menjadi 1.521.2531.168 dari tahun sebelumnya Rasio kemandirian keuangan pemerintah lebih dari $100 \%$ ditandai dengan menurunya bantuan pemerintah pusat dalam bentuk dana perimbangan. 
Tahun 2016, pendapatan daerah mengalami kenaikan sebesar $117 \%$ menjadi 9.973.988.772 dari tahun sebelumnya sebesar 8.480 .758 .953 dengan sumber pendapatan asli daerah yang berasal dari pajak daerah yang memiliki kontribusi terbesar dengan tingkat kemandirian sebesar yang relatif besar lebih dari $100 \%$ dari tahun sebelumnya. Secara nyata tingkat kemandirian dapat dilihat dari naiknya pendapatan daerah, dan semakin kecilnya pembiayaan daerah di tahun tersebut.

Tahun 2017, kenaikan pendapatan daerah terjadi dalam jumlah yang besar menjadi 12.234.837.882 dari tahun sebelumnya yang hanya 9.973988.772 dengan kontribusi sumber pendapatan terbesar masih diperoleh dari pendapatan pajak daerah. Tingkat kemandirian juga menjadi sngat tinggi di tahun ini ditandai dengan menurun drastis nya bantuan pemerintah menjadi hanya 357.472 dari 1.123 .954 di tahun sebelumnya.

Komponen APBD selanjutnya yang akan dibahas untuk menilai dan menganalisis anggaran keuangan pemerintah adalah dengan menilai struktur belanja. Seperti telah dijelaskan sebelumnya, bahwa komponen belanja yang ada di dalam APBD adalah Belanja Langsung dan Belanja Tak Langsung. Berikut adalah data pengeluaran / belanja pemerintah kabupaten/kota yang ada di Provinsi Sumatera Utara selama tahun 2013 sampai dengan tahun 2017 :

Tabel 2 Anggaran Belanja Pemerinta Kabupaten/ KotaPemerintah Provinsi Sumatera Utara

\begin{tabular}{|c|c|c|c|c|}
\hline No. Jenis Pengeluaran & 2014 & 2015 & 2016 & 2017 \\
\hline $\begin{array}{l}\text { A. BELANJATIDAK } \\
\text { LANGSUNG }\end{array}$ & 5.371 .411 .132 & 5.886083 .698 & 7059489325 & 881.983 .873 \\
\hline $1 \quad$ Belanja Pegawai & 1.008 .161 .979 & 1055299207 & 1371733360 & 214.664 .405 \\
\hline Belanja Bunga & 0 & 0 & 0 & 0 \\
\hline Belanja Subsidi & 0 & 0 & 0 & 0 \\
\hline Belanja Hibah & $1.611 .718 . .257$ & 2094026766 & 3022.816000 & 6.083 .700 \\
\hline Belanja Bantuan Sosial & 1.065 .000 & 0 & & 1.382 .500 \\
\hline Belanja Bagi HasilSharing & $1.692 . .809 .639$ & 2330828370 & 2.478 .630 .055 & \\
\hline Belanja Bantuan Keuangan & 1.053 .174 .611 & 405929355 & 178.809 .910 & 176.773 .002 \\
\hline Pengeluaran Tidak Terduga & 4.482 .346 & 0 & 7.500 .000 & 0 \\
\hline B. BELANJALANGSUNG & 2.437 .145 .478 & 2.073 .083 .486 & 2.891 .355 .120 & 483.080 .468 \\
\hline Belanja Pegawai & 144.540 .209 & 151.092 .148 & 175.532 .064 & 46.841 .165 \\
\hline Belanja Barang dan Jasa & 1.146633 .041 & 989.746 .989 & 1.472 .525 .876 & 196.715 .443 \\
\hline $3 \quad$ Belanja Modal & 1.145 .972 .228 & 932.244 .349 & 1.243 .297 .180 & 239.523 .861 \\
\hline C.Pembiayaan Daerah & 14.897 .905 & 536.489 .675 & 0 & 4.000 .000 \\
\hline JUMLAH/TOTAL & 7823455215 & 8495656859 & 9975112726 & 0 \\
\hline
\end{tabular}

Sumber : Data Olahan (2020)

Berdasarkan data yang ada pada tabel diatas dapat dilihat bahwa pada tahun 2014 komponen belanja pemerintah yang besar berasal dari belanja tidak langsung yaitu senilai $\mathrm{Rp}$ 5.371.411.132 bila dibandingkan dengan total belanja langsung yang hanya Rp 5.371.411.132. Komponen belanja tidak langsung meimiliki nilai yang relatif besar dibandingkan belanja langsung karena terdapat komponen belanja lain yang sifatnya bantuan seperti belanja subsidi, belanja hibah, belanja bantuan sosial dan lainnya. Belanja bagi hasil memiliki nilai tertinggi yaitu $\mathrm{Rp}$ 1.692.809.639 
diantara komponen belanja yang sifatnya bantuan yang lainnya. Pos belanja tak langsung hanya memiliki tiga (3) komponen yaitu belanja pegawai, belanja barang dan jasa, serta belanja modal. Pengeluaran belanja pegawai memiliki kontribusi terbesar dalam komponen belanja tak langsung.

Komponen belanja tak langsung tahun 2015 mengalami peningkatan sebesar $90 \%$ menjadi 5.886 .083 .698 dari 5.371.411.132 di tahun sebelumnya, belanja bagi hasil masih menjadi kontribusi tertinggi pada komponen belanja tidak langsung. Belanja langsung mengalami penurunan sebesar $12 \%$ menjadi 2.073.083.486 dari tahun sebelumnya yaitu 2.437.145.478. Kontribusi belanja pegawai pada komponen belanja langsung mengalami kenaikan menjadi 151.092.148 dari tahun sebelumnya, sedangkan kontribusi belanja barang/jasa serta belanja modal mengalami penurunan dari tahun sebelumnya yaitu masing-masing 989.746.989 untuk belanja barang/ jasa dan 932.244.349 untuk belanja modal.

Tahun 2016, komponen belanja tak langsung naik sebesar $83 \%$ menjadi $\mathrm{Rp} \quad 7.059 .489 .325$ dari tahun sebelumnya. Hal ini terjadi dikarenakan naiknya komponen belanja hibah sebesar 69\% menjadi Rp 3.022.816.000 dari tahun sebelumnya. Komponen belanja pegawai di belanja tidak langsung juga mengalami kenaikan sebesar 76\% menjadi Rp 1.371.733.360 dari tahun sebelumnya. Belanja bantuan keuangan turun drastis sebesar 44\% menjadi Rp 178.809.910 dari tahun sebelumnya. Dan pengeluaran tidak terduga yang nihil di tahun sebelumnya, muncul menjadi $\mathrm{Rp}$ 7.500.000 di tahun 2017. Komponen belanja langsung naik sebesar $72 \%$ menjadi Rp 7.059.489.325 dari tahun sebelumnya Rp 5.886.083.698 ditahun sebelumnya. Kontribusi belanja modal di belanja langsung mengalami kenaikan yang cukup drastis dari tahun sebelumnya, yaitu naik $75 \%$ menjadi Rp 1.243.297.180.

Tahun 2017, komponen belanja tak langsung mengalami penurunan .yang cukup pesat lebih dari 100\% menjadi 881.983.873. Hal ini dikarenakan adanya penurunan yang cukup pesat lebih dari $100 \%$ di 2 komponen belanja tidak langsung, yaitu belanja hibah dan belanja bantuan sosial. Pengeluaran tidak terduga yang sempat muncul di tahun sebelumnya, di tahun 2017 telah nihil kembali. Begitu juga dengan belanja langsung mengalami penurunan sebesar $16 \%$ menjadi Rp 483.080.468 dari tahun sebelumnya, hal ini dikarenakan adanya penurunan di beberapa komponen belanja langsung lainnya seperti: belanja pegawai yang mengalami penurunan sebesar $26 \%$ menjadi Rp 46.841.165, belanja barang/jasa turun $13 \%$ menjadi 196.715.443, serta belanja modal turun $19 \%$ menjadi $\mathrm{Rp} 239.523 .861$ dari tahun sebelumnya.

Dari keseluruhan analisis yang digunakan dalam mengukur kinerja APBD Kota Medan menunjukkan hasil yang cukup baik sehingga dari sisi analisis ini kinerja APBD Kota Tegal menunjukkan hasil yang positif. Diantara analisis tersebut yaitu Sumber pendapatan pemerintah kabupaten / kota yang ada di Provinsi Sumatera Utara mengalami kenaikan setiap tahunnya dari tahun 2014 sampai dengan tahun 2017. Hal ini berarti Kinerja pendapatan pemerintah daerah dikatakan baik apabila mengalami peningkatan secara positif dalam beberapa periode anggaran (Lubis \& Nurlia, 2017). Namun, Komponen pendapatan yang berasal dari dana bantuan pemerintah pusat mengalami 
penurunan dari tahun ke tahun mulai dari 2014 sampai dengan tahun 2017. Kinerja keuangan baik dan tingkat kemandirian keuangan pemerintah daerah mengalami kenaikan yang signifikan dari tahun 2014 sampai dengan tahun 2017. Kenaikan kemandirian keuangan pemerintah daerah ini menunjukkan bahwa dengan adanya pola bantuan pemerintah pusat yang lebh besar bersesuaian dengan kemampuan keungan daerah sehingga kinerja keuangan Kab/Kota Medan dapat dikatakan baik (Ramadhani, 2016).

\section{PENUTUP}

\section{Kesimpulan}

Berdasarkan hasil yang diperoleh dari pembahasan diatas, maka penelitian analisis anggaran pendapatan dan belanja pemerintah kabupaten/kota yang ada di Provinsi Sumatera Utara ini memperoleh kesimpulan sebagai berikut :

1. Sumber pendapatan pemerintah kabupaten / kota yang ada di Provinsi Sumatera Utara mengalami kenaikan setiap tahunnya dari tahun 2014 sampai dengan tahun 2017.

2. Komponen pendapatan yang berasal dari dana bantuan pemerintah pusat mengalami penurunan dari tahun ke tahun mulai dari 2014 sampai dengan tahun 2017.

3. Kinerja keuangan baik dan tingkat kemandirian keuangan pemerintah daerah mengalami kenaikan yang signifikan dari tahun 2014 sampai Saran dengan tahun 2017.

Melalui hasil penelitian ini maka pemerintah kabupaten / kota yang ada di Provinsi Sumatera Utara untuk senantiasa mempertahankan dan meningkatkan kualitas manajemen pengelolaan keuangan daerah agar tetap dalam posisi baik dan mandiri ditandai dengan besarnya komponen pendapatan asli daerah yang terus meningkat

\section{DAFTAR PUSTAKA}

Haryani. (2016). Analisis Kemandirian dan Efektivitas Keuangan Daerah Kabupaten Bireun. Jurnal Kebangsaan. 5(9).

Hiariey, C. (2017). Analisis Kinerja Keuangan Anggaran Pendapatan Belanja Daerah (APBD) Di Kota Ambon. $e$ Repository Sarjana FEB Universitas Gajayana Malang.

Kaeng, A., R., \& Saerang, D., P. (2017). Analisis Pendapatan Asli Daerah untuk Belanja Daerah pada Pemerintah Kota Tomohon. Jurnal EMBA: Jurnal Riset Ekonomi, Manajemen, Bisnis dan Akuntansi, 3(2).

Lubis, D.P.K. \& Nurlia, H. (2017). Analisis Rasio Keuangan Untuk Mengukur Kinerja Keuangan Pemerintah Daerah Kabupaten Labuhan Batu Tahun Anggaran 2011-2013. Jurnal KHITABAH. $1(1)$.

Ramadhani, \& Randria, F. (2016). Analisis Kemandirian dan Efektivitas Keuangan Daerah di Kota Tarakan Tahun 2010 2015. Jurnal Ekonomi Pembangunan. 14(1).

Risyanto, H. (2015). Analisis Kemampuan Keuangan Daerah dan Kemandirian Keuangan Daerah serta Pengaruhnya Terhadap Pertumbuhan Ekonomi Kabupaten Garut Tahun Angaran 2004-2013. Coopetition. 6(1). 
Sinambela, E. (2016). Analisis Kinerja

Anggaran Pendapatan dan

Belanja Daerah Pada

Pemerintah Provinsi Sumatera

Utara. Jurnal Riset Akuntansi dan Bisnis. 16(1).

Suryantini, N.,P (2017). Analisis Kinerja Keuangan Kabupaten/ Kota di Provinsi Bali. Prosiding Seminar Nasional AIMI. 